\title{
Introduction: Public choice at the millennium
}

\author{
William F. Shughart II and Laura Razzolini*
}

Thirty-five years ago, Dennis Mueller was able to survey the field of public choice within the space of an article-length contribution to the Journal of Economic Literature. Fifteen years later, Public Choice II, the second edition of the book expanding on that initial literature review, ran to nearly 500 pages of densely packed text and cited approximately 900 scholarly works. At the dawn of the twenty-first century, attempting to do the field justice within the covers of a single volume has become a daunting challenge. ${ }^{1}$

That is because the ideas and methods elaborated by Duncan Black, Anthony Downs, Kenneth Arrow, James Buchanan, Gordon Tullock, William Riker and Mancur Olson have permeated virtually every recognized area of specialization within the disciplines of economics, political science and, to a lesser extent, sociology. Not unlike the successful inroads made by neoclassical economics itself into research on the family, crime and punishment, and the law, public choice has transformed the study of Homo politicus. If the theories of social science are to be judged by their applications, by their ability to help explain observed human behavior within a particular set of institutional constraints (and even to help illuminate the design of the institutions that impose those constraints), then public choice has perhaps been the most successful theoretical innovation to have appeared in the past halfcentury or so. By Kuhnian (Kuhn 1970) standards, public choice truly has been revolutionary.

The established paradigm challenged by public choice is customarily referred to as the public-interest theory of democratic government. That theory presumes unselfish benevolence on the part of the government actors to whom ordinary citizens delegate decision-making authority. Be they elected representatives or full-time government employees, these actors are portrayed in the older way of thinking as public 'servants' motivated only by a desire to maximize society's welfare. Moreover, the public-interest model presumes that the social preferences to which government actors faithfully respond can be ascertained readily through the workings of the democratic process. Once the 'will of the people' is thus determined, the public sector's decision makers can move quickly to supply public goods in desired quantities, to intervene remedially in the economy when markets fail to produce Pareto-efficient allocations of goods or of productive resources, and to redistribute incomes more fairly. 
Public choice is frequently defined as the application of economics to the study of politics. That definition highlights the subject's interdisciplinary character, places it squarely within the positive tradition of economic science that demands models, refutable predictions, and empirical tests, but, what is more important, it emphasizes the methodological individualism of economic analysis that public choice brings to the study of problems formerly the exclusive province of political scientists and sociologists.

Economics treats the individual actor as the fundamental unit of analysis. In ordinary markets, that individual actor is a person who, as a consumer, strives to maximize his own sense of wellbeing, given the constraints imposed by a limited budget and the prices of available goods, who, as a worker, strives to maximize his income, given his native talents, the skills he has acquired, and his tastes for work and leisure, and who, as a business owner, strives to maximize his profits, given the constraints imposed by technology, by the costs of inputs and the tastes and preferences of buyers. No matter what role he plays, however, the individual actor is assumed to be guided largely by self-interest.

While for model-building purposes 'self-interest' is frequently construed narrowly to mean wealth maximization, the rational actor model is in fact much more general. Economists assume that individuals pursue the maximization of utility, of which money wealth is only one component, thereby allowing for the fact that human action is guided by a variety of goals and objectives, including solicitude for the welfare of others. Choices are made by rational economic actors with reference to judgments about which of the available alternatives provides the greatest sense of personal satisfaction, and satisfaction can be derived not only from actions that increase the decision maker's own happiness, but from those that enhance the wellbeing of family, friends, neighbors, and society at large.

Two implications follow immediately from transferring this rational actor model of economic theory from the realm of ordinary markets to the realm of politics. First, actors in the public sector can be portrayed as having motivations similar to those attributed to actors in the private sector. Self-interest and not the public interest becomes the most important behavioral stimulus. Elected officials strive for re-election. Appointed officials strive to secure larger agency budgets and to advance their careers. Voters strive to make themselves personally better off. Realism displaces wishful thinking; human behavior is seen as consistent, the behavioral system is closed (Buchanan 1972). Public choice does not deny the possibility of public-interest motivations, but it insists that that model be stated in testable form.

Second, by adopting the methodological individualism of economic theory, public choice rejects the construction of monolithic decision-making units, such as 'society', the 'people', or the 'community'. Only individuals make 
choices. The problem then becomes how to model the process by which the various preferences of rationally self-interested individual actors get aggregated when decisions must be made collectively.

One of public choice's key insights is that political outcomes differ from market outcomes, not because the behavioral motivations of individuals are different in the two settings, but because the institutional frameworks within which rational actors pursue their self-interests differ. Private choices take place within the context of a system of well-defined and -enforced property rights that generate price and profit signals to which individuals have powerful incentives to respond; public choices take place within the context of ill-defined property rights that force decisions to be made without the benefit of explicit price and profit signals. Private choices are unilateral; public choices are multilateral. Private choices entail consequences that are in large measure borne by the decision maker himself; the benefits and costs of public choices must be shared with others. Individuals participate in private transactions voluntarily; if they find themselves in the minority, their participation in public transactions may be coerced. Private exchanges are positive sum; exchanges mediated by the public sector may be zero sum or negative sum. Competitive market conditions provide buyers and sellers with alternatives to which they readily can turn; monopoly in the public sector provides limited options among which the costs of switching tend to be high.

Within the institutional framework of markets, profit-seeking firms have strong incentives to use productive resources efficiently and to serve their customers well. Prices are kept in line with costs, factor payments reflect marginal productivities (the distribution of income mirrors contributions to value), and the sum of consumer and producer surplus is made as large as possible. To be sure, market institutions may sometimes fail to achieve Pareto efficiency. When property rights are not well defined, there may be social benefits or costs associated with private market activities which individual decision makers do not take into account but which affect third parties positively or negatively. In the presence of transaction costs that prevent bargaining to internalize such externalities (Coase 1960), some goods (education, for example) may be undersupplied by private markets and some 'bads' (pollution) may be oversupplied. Common pool resources will tend to be overutilized and some public goods may not be supplied at all if left to the private sector. Private sellers may have informational advantages over buyers or possess market power that allows them to elevate their prices and profits at consumers' expense.

While such potential market failures provide scope for remedial government intervention, the application of public choice principles to the policy responses prescribed by orthodox social welfare theory (Pigou 1920; Samuelson 1954) warns that the public sector itself may likewise fail to 
achieve Pareto-efficient results. The information available to government decision makers about the costs and benefits of corrective action is necessarily incomplete and biased toward the alternatives preferred by those individuals and groups having the greatest stakes in the policy options and the most means to reward or punish policy choices. Coupled with rational ignorance on the part of the mass of voter-taxpayers, the rationally self-interested behavior ascribed to policy makers by the public choice model provides no assurance that public goods will be supplied in ideal quantities or that other perceived sources of market failure will be rectified cost-effectively. The imbalance between the social costs and benefits of intervention and the personal costs and benefits confronting those having the authority to intervene may well lead to the adoption of policies that, while privately beneficial to the policy makers themselves and to the special interests on which they rely for political support, reduce society's welfare overall. Pork barrel, a public sector that expands continuously in size and scope, and a mix of policy interventions that interferes with rather than enhances the workings of private markets are the predictable outcomes of political processes analysed from a public choice perspective.

If public choice processes cannot be relied upon always to produce Paretoefficient results, then decisions about the constraints imposed on those processes become of first-order importance. The second key insight of the public choice model is that political institutions matter. Institutions determine which activities will be undertaken by the public sector and which will be undertaken by the private sector. Moreover, for those activities that are shifted to the public sector, institutions establish the decision rules that will determine outcomes. Can action be taken by a plurality, a simple majority, or will the agreement of a more inclusive set of voters be required? In short, if actors in the public sector have the same behavioral motives as actors in the private sector, what 'rules of the game' will be chosen to govern the political process, that is, to help align private interests with the public interest?

These themes are elaborated in a variety of contexts by the contributors to this volume, and we shall summarize many of the insights offered by the public choice model in our précis below. Before doing so, however, it is useful to address some broader questions. We begin by considering three concerns broached by the critics of public choice. The next section explores the morality of public choice. Subsequent sections deal with ongoing debates about the efficiency of political markets and the value of public choice prescriptions for institutional reform. Finally, we delve into the timing of the public choice revolution: why did public choice emerge in the 1950s and 1960s rather than earlier or later? 


\section{Is public choice immoral?}

To paraphrase William Mitchell's apt analogy (see Chapter 1 of this volume), if orthodox welfare economics can be thought of as a pathology of markets, public choice is a pathology of politics. Scholars working in the tradition of Pigou seem to find market failures demanding remedial action on every street corner; scholars working in the public choice tradition seem to find the seeds of government failure in every public program and policy. Indeed, 'one of the most important contributions public choice has made to our understanding of how political systems work has been to demonstrate the serious shortcomings of the simple majority rule' (Mueller 1997, p. 137).

One need look no further than the work of two of the founders of modern public choice, Duncan Black and Anthony Downs, to see the source of the uneasiness created in some minds when forced to confront what in James Buchanan's (1979) artful phrase is 'politics without romance'. Studying collective decision making by committees, Black (1948a, b) deduced what has since been known as the median voter theorem. ${ }^{2}$ If voters' preferred outcomes can be arrayed along a single dimension (for example, left-right), preferences are 'single-peaked' (have unique maxima), and decisions are made by simple majority rule, then the preferences of the voter at the median of the preference array will be decisive. Any proposal to the left or the right of the median will be defeated in a majority-rule election by one which is closer to the median voter's preferred outcome. Because extreme proposals lose to centrist proposals under the assumptions of the median-voter theorem, candidates and political parties will move toward the center and, as a result, their platforms and campaign promises will tend to differ only slightly. Reversing 1964 presidential hopeful Barry Goldwater's catchphrase, majorityrule elections will present voters with an echo, not a choice.

Anthony Downs (1957) added a second reason why voters might find participatory democracy to be instrumentally unrewarding under simple majority rule. Modeling the decision to vote in a rational choice context, Downs concluded that the costs of voting (registering, going to the polls, marking ballots) will almost always exceed the associated benefits. That is because the probability of an individual's vote being decisive (determining an election's outcome) is vanishingly small. If there are $N$ voters and two choices (candidates) on the ballot, one person's vote will be decisive only if the votes of the other $N-1$ voters are evenly split. And as $N$ becomes large, that probability quickly approaches zero. Hence, if voters are narrowly rational, evaluating the act of voting purely in benefit-cost terms, they will not vote. The 'paradox of voting' to which Downs's analysis gave rise asks not why voter turnout rates are so low in democratic elections, at least in the recent American experience, but rather why millions of voters participate in an activity that fails a benefit-cost test. 
The two implications produced by the work of Black and Downs, namely that the options presented to voters will not be very sharp and that the act of voting is narrowly irrational, lie at the heart of concerns that public choice endangers the democratic process by subverting the values on which its operation depends. If popular support declines, the public sector's ability to act for the public good will be compromised. Government will lose its legitimacy. These concerns are reinforced by subsequent theoretical contributions that demonstrate the impossibility of a social choice mechanism having desirable democratic properties (Arrow [1951] 1963), attribute parochial motives to government bureaucracies (Niskanen 1971), see regulatory agencies as being vulnerable to 'capture' by the firms they are responsible for regulating (Stigler 1971; Peltzman 1976), and portray politicians not just as beholden to special interests, but as active brokers of wealth transfers among them (McCormick and Tollison 1981).

As one critic puts it, the 'tragedy of public choice' is that

cynical descriptive conclusions about behavior in government threaten to undermine the norm prescribing public spirit. The cynicism of journalists - and even the writings of professors - can decrease public spirit simply by describing what they claim to be its absence. Cynics are therefore in the business of making prophecies that threaten to become self-fulfilling. If the norm of public spirit dies, our society would look bleaker and our lives as individuals would be more impoverished. (Kelman 1987, pp. 93-4)

But public choice no more denies the existence of 'public spirit' than economics denies the existence of altruism. Specialists in neither field have ever argued that self-interest is the only motivator of human action. Rather, the shared assumption of economics and public choice is that self-interest is the most important of the many and varied forces that animate the behavior of complex individuals. The basis of this assumption is not unrelieved cynicism about the human condition, but rather confidence in the results of repeated empirical testing showing that models based on self-interest do a better job of explaining observed behavior than models based on alternative behavioral assumptions. And, to reiterate, self-interest is a broad concept.

Although public choice, like economics, has significant normative content, the value of the assumption of self-interest lies not in its realism, which can be debated endlessly, but in its contribution to the explanatory powers of the positive theories grounded in it. To be sure, there might be something called 'public spirit' that motivates individuals in the realm of civic life, but how can it be measured and what are its testable implications? An even more important question is, can those implications be refuted? Variations in voter turnout rates over time might depend on the ebb and flow of public spirit. The same data might also be explained by changes in the underlying benefits and costs 
of voting facing a rationally self-interested citizenry. While the latter hypothesis can be (and has been) tested by public choice scholars, admittedly with only mixed success, the former is essentially little more than an ex post rationalization with no predictive power. We might attribute increases in voter turnout to a rise in public spirit, but it is not clear that we have done anything more than state a tautology. Resort to 'public spirit' is the same as attributing bull markets to Keynesian 'animal spirits' or Greenspanian 'irrational exuberance'. Still, people do vote. A sharper distinction between voting as an investment in electoral outcomes and voting as a consumption activity might help resolve the paradox.

An increase in the supply of volunteers willing to fight a 'popular' war might likewise be evidence of public spirit. Enlistment might also be a calculated decision based on the expectation that volunteers get better military assignments than draftees or that failure to participate invites social stigmatization that will adversely affect the slacker's post-war income-earning abilities. In times of crisis or national emergency, selfish and selfless motives doubtless influence every person's decision-making calculus to varying degrees. $^{3}$

The public choice model does not rule out the possibility of public spirit, because it cannot be ruled out. The methodology of public choice places selfinterest at center stage, at the same time recognizing that the motivations of human beings are much richer than can be accommodated by the simplified rational actor model. Individuals do make donations to charitable causes, but only a model built on self-interest can explain why charitable giving tends to be higher the more favorable is its tax treatment (Clotfelter 1980). Individuals do register to vote and go to the polls, but only a model built on self-interest can explain why voter registration rates tend to be lower the greater is the registered voter's vulnerability to being called for jury duty (Knack 1993). ${ }^{4}$

The positive insights into political processes contributed by public choice scholars are neither moral nor immoral; they simply describe how those processes work. Knowing the outcomes produced by particular political institutions is especially valuable when the perspective shifts 'away from the analysis of policy choice by existing agents within existing rules, and towards the examination of alternative sets of rules' (Brennan and Buchanan 1988, p. 187; emphasis in original). Because the public choice perspective sees policy outcomes as depending, not on the behavioral motivations of the policy makers themselves but on the constraints imposed on their policy choices by the institutional 'rules of the game', policy failures can be corrected only by changing the constraints. If all agents are self-interested, it will do no good to replace one set of them with another. Appeals to policy makers' senses of propriety or public spirit will fall on deaf ears. 'Better' people will not make 'better' government, and no amount of preaching can 
transform basic human nature into something nobler. Meaningful reform requires changing the institutional rules in ways that more closely align policy makers' self-interest with the public's interest.

Hence, the morality of public choice is found in its ability to illuminate the behavior of living, breathing political actors operating under the rules at hand and, in so doing, to suggest ways in which the rules might be changed to improve observed outcomes. Dispelling blind faith in the institutions of governance may be distressful for some, but the hardnosed analysis of political processes brought to bear by public choice offers prescriptions for improvement that cannot be deduced from any other known model. Far from undermining confidence in the workings of democratic government, by pointing the path to substantive reform, public choice can help strengthen it.

\section{Are political markets efficient?}

While acknowledging the value of the rational actor model as an engine of positive analysis, some critics of public choice have nevertheless argued that democratic political markets produce outcomes that are every bit as efficient as the outcomes produced by ordinary markets. The most eloquent of these critics, Donald Wittman (1989, 1995), contends that public choice has failed to appreciate the power of competition between interest groups and between political entrepreneurs to squeeze out inefficiencies from political exchanges and, hence, to generate a set of political institutions and a mix of public policies that ensure the realization of all potential gains from political trade. In the best Chicago-school tradition, Wittman maintains that what is, is efficient. Were it not, that is, were it possible to increase the efficiency of a particular government program or policy in the Paretian sense, thereby making at least one person better off without making anyone else worse off, the welfare- (wealth-) enhancing change would already have been implemented because it is in somebody's self-interest to have done so. Government failure is therefore only a 'myth', or at least political failures are no more severe in the public sector than market failures are in the private sector.

Wittman reaches this conclusion by distancing himself from the operating principles of public choice. In Wittman's world, voters are well informed about the impacts of government programs and policies on their personal welfare, political markets are robustly competitive, and transaction costs in these markets are not excessively high. Under such assumptions, incumbent politicians and policy makers must select efficient methods for achieving desired ends or lose their offices to rivals who will do so. This means not only that the particular policy tool chosen (taxes versus regulation, for instance) must obey Paretian principles, but that the decision to intervene in the first place must satisfy the same efficiency criteria: government will only undertake those activities in which it has a comparative advantage. ${ }^{5}$ If political 
market conditions allow for intervention into private markets, however, government will intervene in the most efficient way possible.

Consider one of Wittman's many examples. Economists since the time of Pigou (1920) have extolled the efficacy of pollution taxes as ways of forcing firms to curtail their discharges of environmentally harmful toxic wastes. Yet apparently less-efficient command-and-control regulation mandating the adoption of specific pollution abatement technologies has long been the policy tool of choice for internalizing the externality. Wittman (1995, pp. 118-21) emphasizes that the relative efficiency of pollution taxes depends critically on regulators having precise and detailed information about the marginal benefits and costs of pollution abatement. If such information is available, then taxes can be set optimally and that policy tool is indeed more efficient (generates smaller deadweight costs) than regulation. But if information is imperfect (as it is likely to be), regulation is superior to taxes under certain circumstances. $^{6}$

The controversial conclusion reached by Wittman in this situation and many others is not that tradeoffs must be made in choosing appropriate policy tools, but that democratic processes can generally be relied on to select the most efficient of the available options. Comparing command-and-control regulation with more market-friendly approaches to externality, Gary Becker (1976a, p. 247) stated the case in the strongest possible terms by suggesting 'that the traditional emphasis on the waste caused by industrial regulation be reversed: regulations that survive the keen competition for votes tend to be relatively efficient ways to redistribute resources'. Disputing the received wisdom of neoclassical economic theory that cash transfers are always preferred to in-kind transfers as ways of redistributing wealth, Becker (p. 247) writes that 'if quotas are used instead of cash, the dead weight loss from cash must exceed that from quotas; otherwise, the number of votes would not be maximized, and could be increased by replacing the quotas by cash' (emphasis in original). The prescriptions of theory notwithstanding, 'economists are no more able to discover better ways to redistribute than they are able to discover better ways to produce the products of business' (p. 248).

In short, a vigorously competitive political marketplace populated by votemaximizing politicians and reasonably well-informed voters tends to minimize the excess burdens of taxes and the deadweight costs of regulations (Becker 1983, 1985). This is not to say that government waste does not occur or, in fact, that the waste is not considerable. The key implication of the preceding analysis is rather that alternative means of achieving desired policy objectives carry higher deadweight costs per dollar redistributed than do existing means.

Although pressure groups play roles in Wittman's analysis, they do so primarily as conduits of information to the politicians who make policy choices and to the voters who elect them. Majoritarian interests dominate 
special interests. Congress regularly rejects stringent gun-control legislation and regularly votes to increase veterans' benefits not because of intense lobbying by the National Rifle Association and the American Legion, but because those actions reflect majority opinion as evidenced by the results of voter referenda in California (Wittman 1995, pp. 83-4).

The proof of the pudding is in the tasting. While Wittman's analysis clearly would be undermined by evidence that voters are ignorant (Boudreaux 1996b; Rowley 1997) or that political markets are less than perfectly competitive because barriers to entry are high (Lott 1997), the scientific value of the efficiency postulate will ultimately depend on its empirical content. Is it superior to competing models in predicting which policy tool will be chosen in particular circumstances? Are existing policies in fact efficient? Conducting such tests will not be easy, given that one must consider the welfare costs of alternative government policies to all affected groups. A comparison of the efficiency of sugar tariffs relative to the payment of cash subsidies to sugar growers, for example, requires evaluating not only the deadweight costs of the two policies in the market for cane sugar but the impact of trade protection versus subvention on input markets as well as on the markets for substitute sweeteners (for example, beet sugar and high fructose corn syrup).

One important limitation of the efficiency postulate is its failure to incorporate the costs of rent seeking into the welfare analytics of political-market outcomes. Only the deadweight costs of alternative policies enter into the determination of efficiency. If, on the other hand, some or all of the value of the wealth transfers brokered by government is converted into social costs (Tullock 1967b), then existing institutions and policies may no longer be superior to the available alternatives. This criticism is especially telling in light of the incentives of the current beneficiaries of wealth transfers to defend their rents against attempts to expropriate them. Rent defending may produce a bias in favor of the status quo, even when the status quo is inefficient. $^{7}$

The efficiency postulate advanced by Becker and Wittman raises a challenge to the public choice perspective that has not yet been resolved - and is not likely to be without considerable additional work. But as a positive proposition, it deserves its day in court.

\section{Is constitutional political economy valuable?}

One of the path-breaking contributions of The Calculus of Consent (Buchanan and Tullock 1962) was to focus attention on the document - the constitution - that creates the institutions and establishes the rules under which the political process subsequently plays out. If voters are not well informed, if incumbency confers substantial benefits on the politicians currently in office, and if special interests dominate political processes at the expense of 
majoritarian interests, then the constitution imposes the only operative check on 'in-period' politics.

The importance of constitutional constraints was recognized by James Madison in The Federalist No. 51, where he staunchly defended the federal principle as the most effective guardian of minority interests and the chief counterweight to potential government abuse:

But what is government itself, but the greatest of all reflections of human nature? If men were angels, no government would be necessary. If angels were to govern men, neither external nor internal controls on government would be necessary. In framing a government which is to be administered by men over men, the great difficulty lies in this: you must first enable the government to control the governed; and in the next place oblige it to control itself. A dependence on the people is, no doubt, the primary control on the government; but experience has taught mankind the necessity of auxiliary precautions. (p. 356)

The general question raised by the constitutional perspective is, what set of rules would rational individuals collectively agree to in order to ensure that they will all be better off after the government is formed than they are in some pre-constitutional 'state of nature'? To motivate their analysis, Buchanan and Tullock (1962, pp. 63-91) assumed that individuals were uncertain about whether they would be in the majority or the minority in any future (postconstitutional) collective decision. Constitutional design, in other words, takes place behind what John Rawls (1971) later called a 'veil of ignorance'. Moreover, to ensure that everyone would in fact be made better off, Buchanan and Tullock assumed further that acceptance of the constitution requires unanimous consent so that any one person may veto a provision that threatens to lower his own welfare (Wicksell [1896] 1967).

Constitutional choice in this model requires an analysis of two types of costs involved in making any collective decision. The first of these are decisionmaking costs, the direct and indirect (opportunity) costs of gathering information, negotiating, and reaching agreement on a common course of action. The magnitude of these costs depends on the fraction of the voting population whose consent is required for a particular option to be selected. If one may choose for all (dictatorship), these costs will be zero. Decisionmaking costs rise as the required majority rises and they reach a maximum with a rule of unanimity that allows one to block action agreed to by all but one.

The second category of costs is external costs, which measure the reduction in wealth or welfare that members of the minority can expect to endure as a result of actions taken by the majority. These costs will be at a maximum with dictatorship, since a dictator is likely to place little weight on the costs his decisions impose on others. External costs then fall as the required major- 
ity rises, reaching zero with a rule of unanimity under which decisions are blocked unless everyone is made better off either in fact or through the payment of the compensation necessary to secure consensus. Only Paretosuperior proposals pass.

The optimal majority minimizes the sum of decision-making costs and external costs. At this optimum, the expected marginal gain from reducing the external costs of collective action just balances the expected marginal decision-making cost of increasing the required majority. Several important implications follow immediately from this analysis. First, there is no particular reason why the cost minimum should occur just to the right of 50 per cent (simple majority rule): 'at best, majority rule should be viewed as one among many practical expedients made necessary by the costs of securing widespread agreement on political issues when individual and group interests diverge' (Buchanan and Tullock 1962, p. 96). Second, nothing in the theory requires that the same voting rule be used for all collective decisions. Other things being equal, more inclusive voting rules are optimal when external costs are high relative to decision-making costs and less-inclusive rules are optimal when the configuration of costs runs in the opposite direction. Third, 'it is rational to have a constitution' (p. 81; emphasis in original). That document's purpose is to define the range of decisions that will be governed by collective choice processes and to specify the particular decision-making rule to be used in each case. Generally speaking, while the 'analysis suggests that the individual will choose to shift more activities to the public sector the more inclusive is the decision-making rule' that will govern those activities (pp. 82-3; emphasis in original), the key point is that these decisions are interdependent.

This last implication is crucial if a constitution is to have substantive effect: 'if a single rule is to be chosen for all collective decisions, no constitution in the normal sense will exist' (p. 81). The external costs of some decisions are so great that they should not be made without the agreement of a qualified majority approaching unanimity. A constitutional proscription is equivalent to imposing such a collective decision-making rule. For example, the introductory phrase of the First Amendment to the US Constitution, 'Congress shall make no law', recognizes that the freedoms of religion, speech, press, and peaceable assembly are so essential to individual liberty that it would be foolhardy to allow proposals to abridge them to be subject to ordinary democratic processes. Any collective action is ruled out unless it first secures the broad consensus necessary to amend the Constitution's language.

A constitution, in other words, imposes constraints, thereby setting the 'rules of the game'. It specifies the powers delegated to government (that is, those activities to be governed by ordinary democratic processes). It may go further to enumerate activities subject to more inclusive voting rules, includ- 
ing procedures for amending the constitution, or to prohibit certain actions altogether. ${ }^{8}$ But in any case, the constitution must bind. If anything and everything is subject to the whims of the majority, there is no constitution in any meaningful sense.

The erosion of constitutional protections and the consequent expansion in the size and scope of the federal government that began during the American Civil War and was accelerated by the Great Depression (Higgs 1987; Couch and Shughart 1998) is testimony to the importance of binding constraints and of the dangers of failing to respect them. Even the most ardent of the federalist supporters of a strong central government, Alexander Hamilton, would be stunned by the extent to which national authority intrudes at the end of the twentieth century:

\begin{abstract}
Allowing the utmost latitude to the love of power which any reasonable man can acquire, I confess I am at a loss to discover what temptation the persons entrusted with the administration of the general government could ever feel to divest the States of the authorities of that description. The regulation of the mere domestic police of a State appears to me to hold out slender allurements to ambition. Commerce, finance, negotiation, and war seem to comprehend all the objects which have charms for that passion; and all the powers necessary to those objects ought, in the first instance, to be lodged in the national repository. The administration of private justice between the citizens of the same State, the supervision of agriculture and of other concerns of similar nature, all those things, in short, which are proper to be provided for by local legislation, can never be desirable cares of a general jurisdiction. (The Federalist No. 17, pp. 167-8)
\end{abstract}

Federal legislation funding 100000 police or subsidizing the price of milk may have been inconceivable to the Founding Fathers, but represents business as usual for today's members of Congress.

Constitutional public choice supplies a way of thinking about rule design and emphasizes the importance of the role institutional rules play in determining the outcomes produced by political markets. As such, it has a strong normative flavor. How, in other words, should political institutions be designed? The constitutional perspective does have positive implications as well, though. Developers write 'constitutions' for condominiums and other collective homeownership arrangements, presumably with an eye toward maximizing the return on their investments (the aggregate value of the development's housing units). Among other things, these constitutions contain provisions allocating voting rights to homeowners with respect to decisions setting the monthly fees charged for maintaining the development's grounds, building exteriors and other 'public goods', such as swimming pools and tennis courts. These voting rights become operative after a pre-specified number of housing units have been sold and governance authority is transferred from the developer to the homeowners' association. Studies by Barzel and Sass (1990) and Sass (1992) 
suggest that developers are inclined to write constitutions incorporating modes of representation and voting rules that balance the decision-making costs and external costs of collective action. For instance, the more heterogeneous is the association's membership (the greater the variance of housing unit values), the more inclusive the voting rule tends to be.

Hence, the Buchanan-Tullock model seems to be broadly consistent with the provisions of extant constitutions. Such empirical findings have obvious practical implications for the constitutional transitions under way in many corners of the globe.

In that vein, it is important to think about how constitution makers might be expected actually to behave. Will new constitutions be written and existing constitutions amended behind a veil of ignorance where self-interest is muted, or will constitutional change be influenced by the same forces that tend to dominate ordinary political processes? Much of the available evidence seems to support the latter conclusion. In his pioneering analysis of the US Constitution, Charles Beard ([1913] 1986) argued that the Founding Fathers, whose own personal wealth was based largely on land and slaves, wrote a document designed to protect the interests of their fellow aristocrats at the expense of the propertyless masses. More recently, Anderson et al. (1988a) suggest that the constitutional provision banning the importation of slaves after 1808 and imposing an import duty not to exceed $\$ 10$ per head until then (Article I, section 9) fostered an internal market in slaves that benefited the slave owners in the upper South who dominated the Constitutional Convention. Systematic analyses of votes taken during the 1787 'constitutional moment' in Philadelphia point to self-interest as a driving force in the writing of the US Constitution (McGuire 1988; McGuire and Ohsfeldt 1986).

On the other hand, David Friedman contends (not to our knowledge published) that, because everyone would realize that the aggregate welfare cost of enshrining personal advantages in the constitution would exceed the value of the benefits thereby gained, the delegates to a constitutional convention would have incentives to overcome the temptations of self-interest. Similarly, Holcombe (1992) concludes that when the writers of the constitution of the Confederate States of America had the opportunity to revisit the US Constitution after about 70 years of experience with it, almost all of the changes made were designed to limit the ability of the central government to undertake policies to benefit special interests. The analyses of both Friedman and Holcombe suggest that a general constitutional convention in which the entire document is subject to revision would be less likely to be subverted by special interests than piecemeal reform. In the end, the value of constitutional political economy as a positive theory depends on which of the two foregoing hypotheses is closer to the truth, that is, whether self-interest or public interest will rule constitution writing in practice. 


\section{Why did the public choice revolution begin when it did?}

Although the intellectual roots of public choice can be traced back to the mathematical analyses of alternative voting rules by Jean-Charles de Borda (1781) and the Marquis de Condorcet (1785), the latter of whom ultimately paid the heavy price demanded by Dr Guillotine's sublime invention, leaving aside the related work of a century later by Charles Dodgson ('Lewis Carroll'), modern public choice began in the 1940s with Duncan Black, continued into the 1950s with important contributions by Anthony Downs, and finally took off in the mid-1960s with the publication of The Calculus of Consent (Buchanan and Tullock 1962), The Theory of Political Coalitions (Riker 1962), and The Logic of Collective Action (Olson 1965). Why then? Why not earlier or later?

Scholars are not immune to the influence of events occurring around them (Stigler 1960), and so it is no mystery why, for example, John Maynard Keynes wrote The General Theory of Employment, Interest and Money when he did (1936). Confusing effect with cause, tight money, high tariffs and futile attempts to prop up prices and wages had precipitated global economic free-fall. Production collapsed, unemployment reached historically high levels, and desperate millions turned to government for succor. A theory suggesting that the public sector could prime the economic pump by using fiscal policy tools to stimulate aggregate demand seemed to be just what the doctor ordered.

When we ask why public choice arrived on the scene when it did, the answer is less apparent. We know from James Buchanan's (1992, pp. 5-6) own account the profound influence a chance encounter in the stacks of the University of Chicago's Harper Library with Knut Wicksell's 1896 dissertation, Finanztheoretische Untersuchungen, ${ }^{9}$ had on the formative thinking of one of the field's founding fathers. Marginal personal income tax rates were certainly at prohibitive levels on the eve of the dramatic cuts announced by President Kennedy nearly contemporaneously with the appearance of The Calculus, and perhaps a heavy tax burden spurred interest in theories of Leviathan. But the publication of that path-breaking book antedated the massive expansion of the welfare state fulfilling Lyndon Johnson's vision of the 'Great Society' and bringing Keynesian prescriptions to full flower.

The 1960s were not a propitious time for serious scholarship of any kind, let alone a research program launched in a small Virginia town that gave the impression of being 'conservative'. But positive science will out. Within a quarter-century or so, public choice had colonized most of its sister disciplines and changed the terms of the policy debate. While we may not be able to explain why the public choice revolution began when it did, its ultimate impact is undeniable. 


\section{The Companion's anatomy}

The contributions to the volume are organized under five main headings. William Mitchell opens Part I with a wide-ranging essay that compares and contrasts the operating assumptions and methods of analysis that distinguish the 'Chicago-school' approach to political economy from the public choice logic of the 'Virginia school'. Mitchell places these two schools of thought in historical context and then carefully teases out the points of agreement and disagreement between them, delving into monetarism and rational expectationism along the way. Sharing as they do the assumption that all actors are rational, the differences between Chicagoans and Virginians are not always sharp - indeed, as Mitchell observes, some scholars have their feet in both camps - but fundamentally contradictory conclusions about the efficiency properties of political markets ultimately divide the two groups.

Chapter 2, by Louis De Alessi, brings the modern theory of property rights to bear in discussing the relative strengths and weaknesses of market solutions and government solutions to problems of public goods, externalities, and common pool resources. Ill-defined property rights are in fact the underlying basis of all such market 'failures'. The relevant question then becomes, can government agents allocate resources more efficiently than private agents? Answers to that question turn not on a comparison of imperfect markets with some unattainable ideal (the 'nirvana fallacy'), but on a hardnosed evaluation of the incentives of the relevant actors to recognize potential gains from trade and on the magnitude of the costs of transacting that may impede efforts to take advantage of them. The comparative weakness of property rights in the public sector - the inability of individual agents to personally appropriate gains - suggests that government intervention will rarely improve matters and that, while competition in political markets is better than no competition, these markets will frequently fail to produce efficient results. Markets may not always be perfect, but nor is government. De Alessi's comparative analysis of the imperfect alternatives leads to the conclusion, however, that the public sector's role should be a limited one.

In Chapter 3, Omar Azfar summarizes the seminal contributions of the late Mancur Olson. In The Logic of Collective Action, Olson (1965) questioned the then-common characterization of interest groups as monolithic actors and advanced a theory (sometimes called the 'law of the few') suggesting that group size and cohesiveness are the underpinnings of effective political lobbying. Coupled with a byproduct theory that stressed the value of selective incentives in overcoming rational actors' propensities to free ride, Olson did much to advance our understanding of interest-group dynamics. Dissenting from an overly narrow view of rationality, Azfar recapitulates the rich theory of The Logic and explores some of its many applications, including labor 
unions, global environmental treaties, international alliances, and the impact of interest groups on economic growth.

Part I closes with an essay by Michael Cain on the contributions of Kenneth Arrow, Amartya Sen and other modern social choice theorists (Chapter 4). Taking a methodological approach decidedly distinct from Virginia-school public choice, which begins and ends with the individual as the unit of analysis, these theorists ask whether it is possible to construct a measure of the aggregate welfare of a group of individuals that both respects the values and preferences of the individuals who comprise the group and satisfies a minimal set of desirable normative criteria, such as non-dictatorship. While the short answer at this point seems to be no, in addition to fundamental contributions to theories of voting and institutional design, social choice theory has yielded insights having broader implications for economics, political science and philosophy.

Part II takes up the constitutional framework that imposes structure on the political process. Geoffrey Brennan and Alan Hamlin begin, in Chapter 5, by revisiting The Calculus of Consent (Buchanan and Tullock 1962), the work that triggered renewed interest in constitutional political economy, and then go on to provide an overview of the more recent contributions to this still relatively new area of study. In Chapter 6, Gordon Tullock contributes an essay discussing monarchies and dictatorships, focusing especially on the difficulties autocrats have in holding on to power and of transferring power to successors. Chapter 7, by Tim Sass, closes Part II with a discussion of a fundamental issue in constitutional design, namely the extent to which individuals will participate directly in political decisions. Taking The Calculus as a starting point, he compares the three principal variants of democratic political processes, direct democracy, parliamentary democracy and representative democracy, and summarizes the empirical evidence on the divergent outcomes produced by these alternative constitutional frameworks. Institutions indeed 'matter'.

Following an introductory essay by Mark Crain that highlights the role of institutions in imparting stability to political transactions (Chapter 8), the remaining contributors to Part III look closely at the collective choice machinery characteristic of modern representative democracies. In Chapter 9, Michael Munger surveys theories of voting, comparing the outcomes produced by simple majority rule with alternatives such as the Borda count, shows how majority rule outcomes can be manipulated by strategic voting, and discusses the advantages and disadvantages of systems of proportional representation. The diverse structures and operating rules of US state legislatures are explored by Robert McCormick and Chad Turner in Chapter 10. They then offer new empirical evidence on the determinants of legislator compensation, evidence that supports an efficiency wage theory of politics. 
In particular, rates of economic growth seem to be higher in states where legislators are paid more. Chapters 11 and 12 turn our attention to bureaucracy. William Niskanen's summary of his own path-breaking contributions to the theory of government bureaus, criticisms of that theory, and evolving thinking on the matter, is followed by a wide-ranging survey of recent rational choice theories of bureaucracy, co-authored by Kelly Chang, Rui de Figueiredo, Jr and Barry Weingast, that situate these organizations in a multiple-principal, multiple-agent context. In Chapter 13, Gary Anderson next focuses on the small but growing literature that brings public choice principles to bear in explaining the behavioral motives of the 'independent' judiciary. If all actors are rationally self-interested, judges cannot be treated differently. Anderson summarizes the theory and evidence that lends support to a rational choice perspective on the 'third branch' of government. Political parties and campaign finance are the subject of Kevin Grier's essay in Chapter 14. Following that, Paul Rubin contributes a piece that explores the impact of political ideology on public choice processes (Chapter 15). Part III ends, in Chapter 16, with an essay by Gary Anderson, William Shughart and Robert Tollison summarizing James Buchanan's (1965a) theory of clubs and the numerous empirical implications thereof.

A variety of public choice perspectives on government and the economy is contained in Part IV. Chapter 17, by Robert Ekelund, Jr and Robert Tollison, reviews the theory and evidence of interest-group influence on democratic political processes. Politicians serve as passive brokers of interest-group demands for wealth transfers in that model, but as Fred McChesney shows in the next essay (Chapter 18), they can also actively seek rents for themselves by threatening to expropriate wealth, but forebearing from doing so, in exchange for various kinds of political support. Randall Holcombe looks at the contributions of public choice to orthodox theories of public finance in Chapter 19. In Chapter 20, Richard Wagner examines the links between politics and the macro economy (discussing the theory and evidence on the existence of a 'political business cycle'), Mark Toma places monetary policy in public choice perspective (Chapter 21), and Roger Congleton contributes new empirical evidence showing that spare public choice models do a surprisingly good job of explaining the growth of government in the postSecond World War period (Chapter 22). An essay by Dwight Lee and Jeff R. Clark (Chapter 23) closes Part IV by advancing the provocative hypothesis that there exists an optimal level of trust in government; beyond that optimum, the citizenry's faith in governmental processes is subject to exploitation by those having selfish interests in a larger public sector.

The public choice revolution is documented under the volume's final main heading. Lisa Anderson describes in Chapter 24 how public choice theories, especially those related to the problem of eliciting truthful revelation of 
preferences for public goods, have provided fertile ground for the emerging discipline of experimental economics. Chapter 25, by Robert Ekelund, Jr and Audrey Davidson, puts the power of public choice reasoning to illuminate economic history to successful test. Bruce Benson next (Chapter 26) contributes a detailed survey of the insights gained through the cross-fertilization taking place between public choice and law and economics and, in Chapter 27, Bruce Yandle discusses the inroads made by public choice into the field of environmental economics. The next two chapters, by Gerald Scully (Chapter 28) and Randall Holcombe (Chapter 29), summarize the contributions of public choice to the new thinking on economic development. The emphasis placed by public choice on institutions has borne fruit in a greater appreciation for the role played by 'market-friendly' public policies in explaining why some nations are rich and others poor. The volume ends, in Chapter 30, with Charles Rowley's essay summarizing much that has gone before and placing the international economy in public choice perspective.

\section{Unanswered questions}

The foregoing overview of the main themes struck in this volume indicates, we trust, that the contributions of public choice to the literature of economics and political science have been both wide and deep. This does not mean, however, that all of the important questions raised by the scholars who have sought to apply the rational actor model to politics have been answered or, for that matter, even asked. While public choice thinking has gained wide acceptance in many areas of study (no one any longer takes seriously the idea that traditional economic regulation of price and entry is in the 'public interest', for example), it has been stubbornly resisted in others - antitrust policy being exhibit A (McChesney and Shughart 1995). There is much yet to be done.

The act of voting, that most basic institution of representative democracy, has defied explanation on narrow self-interest grounds. Some inklings of a resolution of the 'paradox' posed by Anthony Downs's (1957) analysis of the vote motive have been advanced in work showing that larger electoral majorities translate into more active lawmaking (Crain et al. 1988b) ${ }^{10}$ and in investigations of voting as a low-cost way of expressing policy preferences (Brennan and Lomasky 1993), but a fully satisfying rational choice model of an essentially irrational activity has thus far remained elusive. Nor have public choice scholars provided an answer to the related question of why much of the wealth redistributed by government flows to groups that tend not to vote at all.

By identifying who wins and who loses when government intervenes to regulate prices and conditions of entry into an industry, public choice (interest-group) models have shed considerable light on the origins of regulation. 
But as the twentieth century comes to a close, the regulatory state is in broad retreat. The commercial airline, motor carrier, banking, and telecommunications industries, among others, have been deregulated, state-owned enterprises have been privatized and, most noteworthy of all, the centrally planned economies of Eastern Europe have collapsed. Not only were these events wholly unanticipated, existing models are of little help in understanding how entrenched interests came to be displaced. More generally, the supply of political entrepreneurship necessary to effect changes in the status quo is still an unopened 'black box'.

A menu of some of the ongoing research questions still facing public choice scholars might take the following form:

- Is voting expressive or instrumental?

- How do interest groups form?

- How efficient is democracy?

- Are the benefits of voting rules more inclusive than simple majority greater than their costs?

- Is constitutional choice different from ordinary choice?

- Why not cash transfers?

- Why are so many government benefits channeled to non-voters?

- Are direct democracies (for example, Switzerland) less protectionist than representative democracies?

- How do the outcomes produced by proportional representation systems compare with geographically based, single-member districts?

- Why does government grow? Or decline?

- What are the effects of fiscal and monetary rules, such as balanced budget requirements or limits on the rate of money growth? Are such rules time-consistent?

- What changes in the political equilibrium trigger privatization and deregulation?

- Why is the 'third way' ('market socialism') so popular?

- Is secession a viable exit option?

- How do political institutions impact economic growth?

- Is money a means of entry into politics or a barrier to entry?

- Why did Bill Clinton 'end welfare as we know it'?

- Why did Richard Nixon go to China?

- Is democracy the 'end of history'?

- How encompassing is a dictator's interest?

Public choice is still young, and so it would be demanding too much to expect answers to every question asked of it. Readers of this volume will see, however, that the rich and varied testable (and tested) implications the public 


\section{choice model has already yielded supply grounds for thinking that the un- answered questions will eventually be answered.}

\section{Notes}

* We benefited from comments and suggestions by Robert Tollison and Hilary Shughart.

1. The collected works of James Buchanan alone fill a 20-volume set in the process of being published by the Liberty Fund. See Buchanan (1999).

2. Black's seminal contributions are reprinted in Black ([1958] 1987). See Chapter 9 of this volume for a formal statement of the median-voter theorem. The work of Harold Hotelling (1929) was an important precursor to Black.

3. The rise of public spirit during national crises provides unique opportunities for the public sector to expand. See Higgs (1987), who documents the growth of government during wars and depressions and suggests that it is not beneath government to manufacture crisis mentalities (for example, the 'War on Poverty') in order to take advantage of the citizenry's greater willingness to cede powers to the public sector.

4. Knack (1993) finds that aversion to jury duty depresses voter registration rates by more than seven percentage points. Based on survey data suggesting that barely half the population professes any knowledge of how juries are chosen, that just 42 percent of respondents believe that jury panels are selected from voter registration lists, and that registration rates are not disproportionately lower for self-employed individuals who face relatively high opportunity costs of jury service, Oliver and Wolfinger (1999) conclude that fear of being called to serve on juries accounts for less than a one percentage point drop in voter registration rates.

5. 'To say that democratic political markets tend toward efficiency does not imply that political markets are superior to economic markets; rather it implies that democratic governments will allocate to economic markets those tasks in which the economic market is most efficient' (Wittman 1995, p. 193).

6. The particular circumstances are that 'government has less information about the marginal benefit curve than the marginal cost curve or when the marginal benefit curve is more elastic than the marginal cost curve' (Wittman 1995, p. 120). To avoid confusion, note that Wittman defines the marginal benefits of pollution from the point of view of the polluter (denominated in profits) and marginal costs of pollution from the point of view of society.

7. Although change is clearly possible - the past several decades have witnessed a wave of deregulation and privatization in the First World and the collapse of communism in the Third - the impediments to reform are nevertheless formidable. See McChesney (1999).

8. Alexander Hamilton (The Federalist No. 84, p. 535) clearly foresaw the 'unintended' consequences of proposals advanced by supporters of the Bill of Rights to enumerate proscribed activities: it might supply an excuse for arguing that powers not specifically forbidden to government have in fact been granted. As he put it,

bills of rights, in the sense and to the extent in which they are contended for, are not only unnecessary in the proposed Constitution, but would even be dangerous. They would contain various exceptions to powers not granted; and, on this very account, would afford a colorable pretext to claim more than were granted. For why declare that things shall not be done which there is no power to do? Why, for instance, should it be said that the liberty of the press shall not be restrained, when no power is given by which restrictions may be imposed? I shall not contend that such a provision would confer a regulating power; but it is evident that it would furnish, to men disposed to usurp, a plausible pretence for claiming that power. They might urge with a semblance of reason, that the Constitution ought not to be charged with the absurdity of providing against the abuse of an authority which was not given, and that the provision against restraining the liberty of the press afforded a clear implication, that a power to prescribe proper regulations concerning it was intended to be vested in the national government. 


\section{xlii The Elgar companion to public choice}

9. Translated by Buchanan under the title 'A new principle of just taxation'. Listed in the references to this volume as Wicksell ([1896] 1967).

10. A recent paper in the spirit of Crain et al. (1988b) by Shachar and Nalebuff (1999) combines notions of electoral 'closeness' with a 'follow-the-leader' model that assumes voters respond to the efforts of party leaders to 'get out the vote' when races are expected to be tight. Using state-level data, Shachar and Nalebuff report evidence suggesting that a one percent increase in the predicted closeness of presidential elections raises voter turnout rates by 0.34 percent. Hence, taking account of the incentives of political elites (leaders of political parties in Shachar and Nalebuff; leaders of interest groups in Crain et al.) to internalize the benefits and costs facing rank-and-file voters may yet help restore empirical credibility to the rational voter model. 